\title{
Correction to: Intraarticular application of autologous conditioned serum (ACS) reduces bone tunnel widening after $A C L$ reconstructive surgery in a randomized controlled trial
}

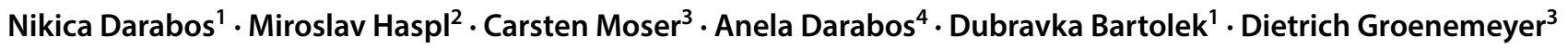 \\ Published online: 22 October 2018 \\ (c) European Society of Sports Traumatology, Knee Surgery, Arthroscopy (ESSKA) 2018
}

\section{Correction to: \\ Knee Surg Sports Traumatol Arthrosc (2011) 19 (Suppl 1): \\ S36-S46 \\ https://doi.org/10.1007/s00167-011-1458-4}

The authors wish to declare the following competing interest, which should have been indicated in the research article.

- The Orthokine ${ }^{\circledR}$ product used in the trial was donated by the manufacturer.

- Co-author Carsten Moser was a medical manager and clinical director for the manufacturer of Orthokine between 2003 and 2008 .

The original article can be found online at https://doi.org/10.1007/ s00167-011-1458-4.

Nikica Darabos

darabos.dr@vz.t-com.hr

Miroslav Haspl

miroslav.haspl@akromion.hr

Carsten Moser

moser@microtherapy.de

Anela Darabos

anela.darabos@vz.t-com.hr

Dubravka Bartolek

dubravka.bartolek1@zg.t-com.hr

Dietrich Groenemeyer

groenemeyer@microtherapy.de
1 University Clinic for Traumatology, Medical School, University of Zagreb, Draskoviceva 19, 10000 Zagreb, Croatia

2 Special Hospital for Orthopaedics and Traumatology Akromion, Ljudevita Gaja 2, 49217 Krapinske Toplice, Croatia

3 Groenemeyer Institute for Microtherapy, University Witten-Herdecke, Universitaetsstrasse 142, 44799 Bochum, Germany

4 Scientific Unit, General Hospital Varazdin, Mestroviceva 1, 42000 Varazdin, Croatia 